\title{
10
}

\section{Rhetorical Methods and Metaphor in Viral \\ Propaganda}

\author{
Chris Miles
}

\section{Introduction}

In this chapter, I will be exploring the phenomenon of viral propaganda through the lens of rhetorical criticism. I will argue that not only are the artefacts of viral propaganda profitably analysed from the perspective of rhetoric but the very idea of the viral nature of propaganda can be understood as a rhetorical construction that influences the way we think (and feel) about certain types of communication. I will be investigating the ways in which viral propaganda and memes have been defined -- in other words, where have these concepts come from, who is using them, and to what purpose? How far, indeed, might it make sense to consider the idea of viral propaganda as a form of propaganda, or even a form of virus, itself?

In order to pursue this exploration, I will first discuss what the terms rhetoric and rhetorical criticism can signify. Rhetoric and propaganda have a very close relationship and it is important for us to understand the ways in which the former can serve the latter (O'Shaughnessy, 2004). Rhetorical criticism thus becomes a valuable method for 
analysing propaganda output and the ways in which that output might seek to win in the 'struggle for perceptions' (Taylor, 2003, p. 8). One of the major stylistic devices of rhetoric is the metaphor, and I will spend a short while discussing the fundamental importance of this figure of speech to the ways in which we view the world. I will then move on to a consideration of the contagion metaphor that is at the heart of the idea of viral communication and propaganda. Calling something viral is a rhetorical choice that is designed to influence the way an audience understands that thing. Again, we need to consider who is choosing this metaphor and to what persuasive purpose? I will examine the marketing roots of the concept of viral communication in order to discuss the strong links between marketing communication on the internet and modern propaganda, and the ways in which communication tools are 'marketed' (by which I mean rhetorically packaged) to political actors.

Internet memes, seemingly the most natively 'web-based' communication tactic in the modern propaganda arsenal, are intimately connected with the idea of viral communication. However, the origins of the meme concept in the final pages of Richard Dawkins' popular genetics classic, The Selfish Gene (2016), originally published in 1976, are often overlooked as is the science of memetics that briefly flourished in its wake in the late 1980s and 1990s. A rhetorical approach to the full spectrum of the discourse around memes and memetics will allow us to more critically consider the nature of internet memes and their place in modern propaganda.

\section{Rhetoric and Propaganda}

Our current attitudes towards rhetoric are inescapably influenced by the ways in which oratory and public persuasion have been framed in our past and there is a deep 
ambivalence towards persuasive speech in Western societies that goes all the way back to Plato and Aristotle. The accusations that Plato makes against the Sophists' focus on persuasive technique are almost identical in sentiment to the way we now tend to talk about 'spin doctors' and political marketers. 'Rhetoric' is the word we use for words that are clearly trying too hard, that we can identify as manipulative, tricky, or mendacious. 'Rhetoric' is empty of real substance and is simply trying to get us to agree. It is the sign of an opportunistic 'gun-for-hire'. It is not to be trusted. Much of this suspicion originates in Plato's dirty propaganda war against the influence of the Sophists on Athenian youth. Indeed, the word 'rhetoric', from the Greek rhetorike has been convincingly demonstrated by Schiappa (1990) to have been coined by Plato with the express purpose of differentiating his philosophy from the sort of relativistic language games that he accused Sophists such as Protagoras, Gorgias, Antiphon, and Isocrates of pursuing. Very broadly speaking, the Sophistic tradition, particularly that carried on in Athens by Isocrates (a famous student of Gorgias), was a clear threat to Plato's vision of a philosophy which was concerned with leading young citizens towards an appreciation of the unchanging, universal truths to be used as a basis for the creation and maintenance of a just and virtuous republic. Plato needed to devalue the power of the Sophists and so created a term, rhetorike, with which to label the Sophistic enterprise so that he was then able to define and gloss this across his dialogues in a manner which lead 'inexorably to the devaluation and the fall of rhetoric' (Cassin, 2014, p. 80). Plato 'discards, devalues, annihilates, phantomizes' (ibid., p. 79) the power that Sophistic practice and performance had given to logos, or speech, ultimately 'taking possession' of it through a cunning (and obviously rhetorical) strategy of 'naming and shaming'. 
However, despite Plato's immense influence on the development of Western intellectual life, his vision of rhetoric did not entirely carry the day. A facility in public speech was, after all, highly advantageous to any citizen who needed to pursue their own interests in the law courts and political assemblies of Athens and, later, Rome. Plato's pupil, Aristotle, adapted to the general demand for education in the art of persuasive speech in his writing of his study of rhetoric, but tried to make of it something more (Platonically) laudable (Reames, 2012). Plato's rhetorike had de-fanged the enchanting power of logos and then, in Aristotle's hands, we see it fully domesticated in its transformation into a techne ruled by a focus upon the internal logic of the matter in dispute, 'leaving us with the proof as the core of rhetoric' (de Romilly, 1975, p. 70). While Aristotle does not deny the capacity of words to pull the wool over the audience's eyes, his emphasis is upon rhetoric as a means to make a true case even stronger, and he starts from a position of 'epistemological optimism' (Wardy, 2005, p. 111), the assumption that truth itself is always naturally more persuasive. The rhetor's job, therefore, is to help show that truth in the clearest, most effective light through the construction of persuasive argumentation.

Still, though, an unease remains. It is particularly palpable in Aristotle's dealing with the subject of rhetorical style, which covers the use of figures of speech, rhythm, patterning, word choice, and so on. Such devices were closely associated with Gorgias, one of the most famous Sophists, and underline the deep psychic effect that the form of words (rather than their substance or the rational arguments that they constitute) can have upon an audience (de Romilly, 1975). Aristotle does not really want to talk about style in persuasive speechmaking as it relies upon the 'baseness of the audience' (2004, p. 216). 
But he knows that he needs to because rhetoric 'has to do with opinion' (ibid.) and therefore should cover those techniques which are necessary and not just appropriate. He does his best, though, to continue Plato's campaign against Sophistic persuasion by admonishing his reader not to fall into the trap of imitating the poetic excesses of Gorgias. Instead, the rhetor should be clear and appropriate, and never draw attention to the artfulness of their speech. This last stricture is one that echoes down through the history of rhetorica docens (or rhetorical instruction) - the orator must always avoid what Cicero calls lingua suspecta (Orator, 145). One should never use language or constructions which might raise the suspicions of the audience that they are the subject of rhetorical designs.

So, although rhetoric became the sign of 'a good man speaking well' (Quintillian, Institutio Oratoria, XII, 1) and formed one of the three pillars of the Medieval trivium, it has always contained within it the seeds of its own downfall. Rhetoric noticed is rhetoric failing. Logical argument, delivered in a plain, decorous style is the mark of acceptable public discourse, but when that logic becomes shrouded in Gorgian metaphor, patterns and stylings designed to enchant an audience's emotions then we risk drawing attention to our efforts. We risk raising up that old Platonic spectre of manipulative, spell-binding logos.

Propaganda is rhetoric, of course. If we use Taylor's (2003) definition of the former as 'a deliberate attempt to persuade people, by any available media, to think and then behave in manner desired by the source' (p. 7) then we are already in the same territory as Aristotle's canonical statement that rhetoric 'is the power to observe the persuasiveness of which any particular matter admits' (2004, p. 74). While rhetoric was born in 
oratorical environments (ceremonial speeches, law court arguments, and political addresses) its principles and techniques were easily adapted to the religious sermon, the letter, the written philosophical argument, and countless other forms of persuasion. Indeed, given rhetoric's importance in the educational programmes of Medieval and Renaissance schooling, it was only natural 'that rhetoric provided the structure underlying all [the] propaganda media' (Loach, 2006, p. 71) employed not only by the Jesuits and the Congregation of the Propaganda Fide but also the Protestant forces against which they competed. Indeed, let us not forget that both St. Augustine and Adam Smith at one point taught rhetoric for a living! Right up until the twentieth century, rhetoric provided the fundamental theory (rhetorica docens) and practice (rhetoric utens) for persuasion whether it be within the pulpit, the law court, the royal court, or the battlefield. As Machiavelli put it in no uncertain terms, an army's generals must be trained orators 'because without knowing how to speak to the whole army, [only] with difficulty can one do anything good' (2005, p. 98). Western propaganda, therefore, ran on the engine of Classical rhetoric until the influence of psychological and sociological research provided alternative frameworks and vocabularies. Yet, even now, it is hard to pinpoint areas in which the social sciences have advanced our practical propaganda arsenal beyond the vast storehouse of techniques provided by the rhetorical tradition. If we simply cast our eyes down the long list of logical fallacies that the study of rhetorical argumentation has amassed over the centuries, we find that the root techniques of modern political marketing and propaganda revolve around such tried-and-tested appeals as those to authority, popularity, pity, false dilemmas, composition, and division. We still see such powerful rhetorical figures as metaphor, metonymy, hyperbole, alliteration, asyndeton, 
polysyndeton, and anaphora at the heart of persuasive political communication. Even an adoption of the 'plain talking' style of the grass roots electorate has a longstanding history as a deliberate rhetorical strategy.

The scholarly method of rhetorical criticism has flourished in the twentieth and twenty-first centuries. While initially focused upon a rather conservative application of the Aristotelian rhetorical schema to the analysis of historically significant pieces of oratory (Black, 1965) it has over the past 60 years transformed itself into a highly variegated collection of foci and methodological approaches which broadly seek to analyse 'any discourse, art form, performance, cultural object, or event that - by symbolic and/or material means -- has the capacity to move someone' (Ott and Dickinson, 2013, p. 2). So, we might think of rhetorical criticism of propaganda as a critical exploration of how language, symbolism, and materials employed in propaganda attempts move the audiences that are exposed to them, with the obvious caveat that what is interpreted by the critic as propaganda is itself subject to rhetorical criticism. Ott and Dickinson (2013) gloss the word 'move' as meaning 'in addition to persuading, inspire, entice, excite, and sway us' (p. 2) and this is a useful reminder that propaganda, like all rhetorical discourse, does not just seek to convince and persuade through what is logical or even likely but just as frequently seeks to move us physically (change our behaviour, get us out on the streets, encourage us to spread the message) by moving us first emotionally. A rhetorical criticism of a propaganda campaign, therefore, might seek to use elements of Classical rhetoric such as the Aristotelian division between proofs of ethos, logos, and pathos to look at the balance between appeals to authority, emotional trigger points, and more reasoned argumentation. It might look at the ways in which enthymemes (or arguments 
based upon premises accepted as probable by the audience) are constructed to carefully resonate with existing audience biases. The propaganda could also be investigated for its use of root metaphors, those wonderfully compressed and powerful figures of speech which have served as the engines for countless 'moving' speeches and communication artefacts. We might equally explore the range of fallacies that a campaign might adopt in its core reasoning, uncovering the logical flaws that nevertheless succeed in seeming logical to particular audiences at particular times. We might also look at the way in which the propaganda constructs its Other, and seeks to undermine alternative perspectives; as Potter (2005) argues, rhetoric can 'be treated as a feature of the antagonistic relationship between versions; how a description counters an alternative description, and how it is organized, in turn, to resist being countered' (p. 108). A researcher could also focus their investigation on the ways in which intertextuality and genre referencing serves to entice an audience or construct an appealing narrative. Or any combination of these and a myriad of other perspectives. Always central to the enterprise of rhetorical criticism, though, is the urge to trace how an artefact, or network of artefacts, might be designed (or serve) to move a particular audience or set of audiences. Let us now, then, perform a rhetorical criticism of 'viral propaganda'.

\section{The Metaphor of Communicative Contagion}

One of the most powerful of rhetorical devices is the metaphor. Technically, a metaphor is the use of a word 'from a lexical field other than that of the subject matter at hand' (Fahnestock, 2011, p. 105). In other words, an 'alien’ word is carried over to do descriptive work in a place it would not usually be found. Metaphors, precisely because they 'need have no previous or easily categorized link' to the words they are being 
carried over to, have the ability to create 'new links, allowing the rhetor to illuminate one term (or concept) by features or senses borrowed from another' (ibid.). A metaphor can allow us, therefore, to entirely change the way that an audience conceives of something. It is a remarkably efficient technique of communication in that it can bring a clear image and its set of associations to the mind, vivifying an idea in an attractive and memorable way. Aristotle noted that 'all conduct their conversations in metaphors' (2004, p. 219) for the metaphor is a ubiquitous aspect of language, not just something occasionally used for persuasive or poetic decoration. Lakoff and Johnson (2003) have famously argued that 'most of our ordinary conceptual system is metaphorical in nature' and that therefore metaphors 'structure how we perceive, how we think and what we do' (p. 4). As Richards (1964, p. 94) succinctly put it, 'thought is metaphoric'. Accordingly, there is a long tradition of rhetorical criticism based upon the analysis of metaphors in persuasive communication, often called 'metaphorical criticism' to delineate its focus (Foss, 2003). One of the classic examples of this approach applied to propaganda, and one which has important ramifications for our consideration of the viral communication in propaganda, is Perry's (1983) analysis of the infestation metaphor in Hitler's rhetoric. Perry contends that 'Hitler's critique of the Jew's status as a cultural being, for example, is not illustrated by the metaphor of parasitism; it is constituted by this metaphor and the figurative entailments it carries' (p. 230). Hitler does not provide a structured, articulated, evidenced argument as to why his audience should see the Jews as parasites. Instead, his use of infestation metaphors to describe the Jews is his entire 'argument'. A metaphor 'can convey a whole body of incipient but shared attitudes and values' and can provide a sort of 'metaphoric logic' which can 'sustain and legitimate such a body of attitudes' (pp. 
230-231). Noting earlier work by Black (1970) and Sontag (1978) on the use of cancer as a metaphor, Perry states that 'disease metaphors are the products of mysteries; they become in turn the producers of mystifications, insofar as they play upon our natural horror of the unknown in order to convey meanings which are left unsaid' (p. 231). He then demonstrates the many ways in which Hitler's discourse used metaphors which described the Jews and the Bolsheviks as 'disease-causing agents', parasites, or poisons which are attacking the 'national body' of Germany. Perry's rhetorical analysis enables us to appreciate the careful 'metaphorical logic' of Hitler's metaphors and how they work to provide a picture of a malignant internal force that has wilfully worked over time to threaten the health of Germany. Importantly, the use of the infestation metaphor also helps to 'remove the moral ambiguities from the prospect of treating the Jews as enemies' (p. 234) as disease-causing agents do not need to be treated with any moral consideration.

Perry's (1983) study is exemplary in its laying bare the workings of metaphor in the service of propaganda. However, it does force us to wonder what type of 'metaphorical logic' might be operating when propaganda is itself labelled viral? The phrase 'viral propaganda' brings a set of associations from the context of disease, bodily invasion, and parasitism (the part of the metaphor that Richards [1964] termed the vehicle) to illuminate our understanding of a particular type of propaganda (the other element of the metaphor, known as the tenor). Given the work of Perry (1983), Black (1970), and Sontag (1978) as rhetorical critics, we would immediately suppose that those who use this metaphor intend to characterise this type of propaganda as nefarious, mysterious, out of control, insidious, threatening - that it to say, all the sorts of things that propaganda has itself used the tenors of virality and parasitism to imply about any particular target. 
So, 'viral propaganda', might be thought to be a pejorative construction, perhaps designed to demarcate certain propaganda outputs as particularly 'virulent' and therefore of more immediate cause for concern. And here, of course, we also walk straight into an old saw of propaganda studies - namely, that propaganda is any statement that comes from the Other, any 'source that we do not like' (Schumpeter, 2003, p. 254n). In this sense, the phrase 'viral propaganda' might be a doubly pejorative rhetorical construction. So, although I might engage in digital communications, my enemy indulges in despicable viral propaganda. Yet, interestingly, this is rarely the case. At the time of writing, a search of Google Scholar for academic works containing the phrase produces surprisingly few results (around 40 hits). Out of these only one (Ganor, 2015) uses the term 'viral propaganda' exclusively to describe communication tactics employed by a clearly marked Other, Islamic State (IS). Ganor (2015) notes that 'the success of its viral propaganda campaign' is one of the main elements that help to 'guarantee that IS will continue to present a significant local and global security threat' (p. 62). It is through the 'skillful wielding' (p. 62) (one notes the sword metaphor) of viral propaganda that IS is able to 'publicize its terrorist acts' (p. 56) and persuade Muslim youth that it is 'the real deal' (p. 62). Ganor's use of the 'viral propaganda' metaphor is rhetorically part and parcel of the larger framing of what he calls the 'war between civilization and barbarism' (p. 63), which is 'a war of values, a war for morality and ideology' (ibid.). More to the point, Ganor sees IS as a 'problem within Islam', a position which is echoed (and so rhetorically strengthened) by his use of the viral metaphor.

However, Ganor's (2015) piece is unusual in its, one might say, traditional use of the viral metaphor. Far more common is an apparently neutral, if not sometimes almost 
celebratory, use of viral framing when scholars talk about propaganda. This seems counter-intuitive when considered within the legacy of rhetorical criticism's investigation of infestation and disease metaphors, though it does have a clear relationship to the ways in which contagion metaphors have been used in marketing communication discourse. As I have demonstrated elsewhere (Miles, 2014), it was marketing that first popularised the idea of viral communication and that drove the rhetorical transformation of the metaphor into something desirable and useful. The first instance of viral marketing was Hotmail`s email service sign-up campaign (starting in 1996) where a short piece of text was automatically attached to the end of every email sent by a Hotmail subscriber informing the recipient that they could also get a free Hotmail account (Marsden, 2006). The text acted in a similar way as a virus inside the email, co-opting the trust that a message from a known source could generate to make the link to the Hotmail sign-up page seem secure and attractive. A very similar strategy was implemented by Apple in its marketing of the iPhone many years later. At almost the same time as Hotmail's marketing campaign began to be rolled out, Jeffrey Rayport (1996) penned a gushing article for Fast Company magazine in which he suggested that marketers should look to imitating 'both biological and computer viruses' (p. 96). Interestingly, Rayport urged marketers to 'stop shying away from the ominous sound of it and embrace the enemy: viral marketing or vmarketing if the term is too harsh' (ibid.). At this early stage, then, the viral metaphor was still unnerving and uncomfortable, something that needed an act of will or some terminological occultation to make palatable. Rayport need not have worried, though. As he indicated, 'every marketer' was 'desperately searching for a new approach to marketing in the post-mass-market economy' (ibid.) and the prospect of a marketing 
technique that could that could in some sense take advantage of hard-to-reach and hardto-understand postmodern consumers and infect them with a hidden message that they would unwittingly, or even gladly, spread across their communities was a hard proposition to ignore. Because that was exactly what viral marketing was - an attractive proposition that marketing gurus could sell to desperate, unnerved marketers who, in turn, could then sell it to their desperate, unnerved clients. A high-profile example of this was Seth Godin, one of the earliest marketing gurus to embrace the potential of the Internet, who published his Unleashing the Ideavirus in 2000, in which he described how an ideavirus can be designed by a marketer so that it 'moves and grows and infects everything it touches' (2000, p. 11.). Godin's book, like countless other articles, blog posts, and even scholarly articles in marketing journals after it, offered a series of rules for harnessing the idea of the marketing virus. What makes a marketing virus shareable? How do you design it for maximum effectiveness? How do you plant the virus in a community? How do you identify the best 'patient zero' to initially infect? The metaphor of biological infection was enthusiastically adopted in a florescence of marketing communication (of agencies and consultancies to prospective clients), marketing scholarship, and journalism (Miles, 2014). The metaphor of infection that is central to viral marketing very quickly lost any sense of being ‘ominous' or 'harsh' (in Rayport's words). This is because it offered marketers the comfort of control. The marketing virus was, ultimately, sold as something which was designed, targeted, and remotely guided by the savvy marketing team. Yes, it used the consumer as a host, but then they were getting entertained by unusual, free content - it was win-win! 
What does this mean for the consumer? While marketers might think the idea of infecting communities of customers and prospects is an exciting technique that puts them back in the driving seat, how might consumers feel about being targets of contagious messages? Of course, one of the great promises of the Internet was that it would make content producers of us all (Hoffman \& Novak, 1996) and this was, indeed, one of the sources of marketer nervousness that viral marketing offered an antidote for. When consumers can potentially communicate across networks with the same speed and reach as a brand, then the balance of power shifts considerably away from institutionalised media and corporate voices. However, it was, perhaps, precisely the fact that consumers were empowered as content producers by the Internet that prevented any form of negative grassroots reaction to the metaphors and practice of viral marketing. Consumers could see that viral marketing was something that can work just as well for them as for any brand. Indeed, it was user-generated content that provided the Internet with its most powerful examples of viral power (Guadagno et al., 2013; Shifman, 2012; Wiggins \& Bowers, 2015). 'Going viral' soon became something that not just an ambitious brand manager could dream of, but anyone with a YouTube account. In this sense, the concept of viral marketing slipped its leash. It would be interesting, perhaps, to examine the relationship between the speed with which many publics forgot (or became inured to) the fear and panic related to early coverage of HIV/AIDS and the speed with which they embraced the metaphor of online virality.

The semantic revision that the adoption of the term represents is something that powerfully demonstrates the alacrity with which metaphorical associations, and their consequent rhetorical uses, can change. As noted previously, most scholarly work on 
propaganda which uses the viral metaphor tends to use it without reference to its negative connotations of infection, infestation, and pestilence. So, for example, Rodley's (2016) study of 'viral propaganda in the 2014 Gaza-Israel conflict' looks at how 'parties on both sides crafted multimodal digital content that sought to interpret, explain or recontextualise the conflict, with the ultimate goal of securing or bolstering support for their cause' (para 6). Rodley (2016) notes that this type of shareable content is 'widely used for marketing' as well as for political communication, and while initially describing its use in the Gaza-Israel conflict as 'viral propaganda' argues that it should more properly 'descried as viral agitprop, in the sense of creative content intended to influence thoughts or behaviours that may or may not be produced by a government or formal institution' (ibid.). Here, Rodley is working with scholarly understandings of propaganda which do not use the term to mark Othered communication. Yet, he is also using the term viral in what seems to be a neutral way, ostensibly shorn of its mysterious 'metaphorical logic' of disease. Instead, the specifically 'viral' content of this propaganda is referred to variously as 'novel', 'stylish', and 'high arousal' (para 13), demonstrating 'a gap between media myth and reality' (para 18), a source of 'meta-mediation' (para 19), as well as 'winning support from foreign audiences, rearticulating national identity, boosting morale, and - through the practice of meta-mediation - neutralising enemy messaging' (para 21). Interestingly, Rodley contrasts viral agitprop with the normal 'practices of online creativity' which produce 'viral content' that are 'participatory and playful' (para 25). So, viral communication is framed here as normally harmless, whimsical, and joyful - it is the context of war which makes it something more sinister. Even then, the serious, sinister side of viral agitprop is framed in a metaphor of mechanisation rather than 
organic infestation or parasitism - Rodley writes of how viral agitprop 'systematises' the culture of playful sharing. In a curious reversal of much journalistic discourse on the power of social media, Rodley actually describes how the military strategic use of viral agitprop is an 'abuse of Facebook' (para. 28). The ramifications of virality as a metaphor for agitprop, then, are simply not examined. Rodley (2016) simply assumes that virality signifies a good thing because it is associated with playful, participatory online content creation.

Evolving Rodley's (2016) approach, Sparkes-Vian (2019) argues that virality in the sense of 'propagation' can, in fact, provide 'a more logical overarching framework for a comprehensive theory of propaganda' (p. 1), one that defines it as 'an evolving set of techniques and mechanisms which facilitate the propagation of ideas and actions' (ibid.) and that therefore can encompass both propaganda and counter-propaganda. So, propaganda does not have to be formally or even informally organised. Rather, an appreciation of the viral nature of modern political communication allows us to realise that propaganda, of whatever type, is always focused on propagation. Again, the metaphor of virality is not examined, just taken for granted.

Now, it as this point that we must consider a term that so far has remained firmly ignored. And that is the word, 'meme'. I would argue that Sparkes-Vian (2019), and many other scholarly investigators into the area of viral propaganda, manages to avoid much reflexive discussion of the nature of communication virality because of this word and what it can be made to signify. Sparkes-Vian (2019) argues that memetics, or the science of memes, 'has considerable analytical and methodological potential with respect to scholarly work on propaganda' (p. 1) and goes on to adopt the 'analytical "toolkit”' of 
'qualitative memetics' in order to analyse the success and failure of memes produced by the right-wing group Britain First and its opponents online. A similar memetic focus can be found in Wiggins' (2016) investigation of online propaganda from both sides of the Ukraine-Russia conflict and in Wall and Mitew's (2018) exploration of the \#DraftOurDaughters 4chan Hilary Clinton attack campaign. In all of these studies, the existence of memetics as a formal methodology is taken largely as read. Rhetorically, 'memetics' function as an ethos argument, or a proof by authority. By taking on the trappings of a science (explanatory diagrams, technical and mathematical terminology) the scholarly use of memetics to describe viral propaganda affords it associations of clinical inevitability and correctness. Wiggins (2016), for example, talks of 'memetic structures' (p. 472) and 'memetic directionality’ (p. 480), while Sparkes-Vian (2019) talks of having to 'disaggregate the memeplex into its constituent alleles' and identifying the techniques 'used to facilitate memetic replication', as well as 'institutional memeplexes' creating 'distinct memetic environments in which the selection pressure on specific memes is altered by the ready acceptance of the basic premises of the ideology'. Meanwhile, Wall and Mitew (2018) talk of the 'topological nature of memetic warfare' and its 'processual aspects' of 'swarm networks' such as 'ideation, rapid prototyping, coordinating, producing and spreading of content by the users'. The metaphorical language here uses a mixture of vehicles drawn from start-up culture management-speak, computer networks, and what seems like evolutionary biology. And while a swarm might well have rather negative biological connotations, it is not the mysterious infecting horror that we can trace in the viral metaphor. Accordingly, in the next section, I consider in 
some depth the rhetorical/metaphorical nature of memetics and the relationship between ‘memes' and propaganda.

\section{Memetics and Persuasion}

The meme is an invention of evolutionary biologist, Richard Dawkins. In one of the final chapters of his book The Selfish Gene (2016), originally published in 1976, Dawkins introduces the idea of the meme as a unit of cultural replication. Just as genes can be seen as using animals, plants, and humans as 'survival machines' (p. 245) to aid in their replication, so also memes use the human brain in order to replicate themselves. A meme is an idea, such as adding yeast to bread to make it rise, or a pattern such as a melody, or even a metaphor. It can be something as grandiose as a religion or something as quotidian as the idea of a belt to hold your trousers up. Memes, in Dawkins view, are the building blocks of human culture. All memes are in competition with another and 'some memes are more successful in the meme pool than others' (p. 251); they get imitated more frequently and spread more quickly from mind to mind. And that is all a meme is - a replicator. It has no other urge or function or 'reason for being' other than to replicate. Human cultures, then, become the collection of (currently) successful memes. Dawkins argues that as they are both simple competing replicators, memes will share the same qualities that genes need for success - 'longevity, fecundity, and copying-fidelity’ (ibid.).

Dawkins' The Selfish Gene has been a tremendously popular book. Indeed, a public poll organised by the Royal Society in 2017 saw it voted the most influential science book of all time (Armitstead, 2017). The 'meme' meme, as it were, has demonstrated an impressive fecundity and longevity. However, its copying-fidelity has perhaps been less 
exemplary. Most users of the Internet today recognise the word almost immediately but do not associate it with Dawkins or even the briefly nascent science of memetics that formed around the idea and attempted to bootstrap itself in the pages of the online Journal of Memetics (the archives of which can be found at http://cfpm.org/jom-emit/). Instead, the word meme has come to refer to a widely shared 'image macro', or an image with superimposed text expressing some comic sentiment, life advice, surreal insight, or, increasingly, politically partisan viewpoint. So, as Marwick and Lewis (2017) note, 'while virtually anything can be a meme since it's a unit of information, in modern Internet parlance, a meme is a visual trope that proliferates across Internet spaces as it is replicated and altered by anonymous users’ (p. 36). There has been a significant amount of scholarship that has attempted to explore the details and ramifications of the memetic concept (Aunger 2003; Blackmore, 2003; Bradie, 2003; Burman, 2012; Calvin, 1997; Distin 2006; Gabora, 1997; Gatherer, 1998; Jantke, 2004; Jeffreys, 2000; Kilpinen, 2008; Lissack, 2004; Marsden, 1998; Rose, 1998; Shifman, 2013; Shifman \& Thelwall, 2009; Zipes, 2008). However, this scholarly literature has been largely divided on the question of whether memes actually exist, and if they do, how might they be most effectively analysed, measured, and described. The Journal of Memetics closed its doors in 2005. As the archive site puts it, 'there was to be a relaunch but after several years nothing has happened'. The concept, in its original expression, proved just too problematic to get enough confident traction. As Shifman (2013) puts it, it was 'the subject of constant academic debate, derision, and even outright dismissal' (p. 362). In the meantime, though, the meme concept successfully mutated into a new form. 
As the Internet was transformed from a largely academic research network into the highly complex, variegated ocean of content creation, dissemination, and consumption that it is now, the dynamics of sharing became more and more central to its nature. Whole layers of the web became organised around encouraging and facilitating the rapid sharing of URLs, videos, images, and audio, as well as personal information, opinions, and 'status'. Microblogging services such as Twitter, content sharing platforms like YouTube, SoundCloud, Imgur, and The Pirate Bay, as well as social networking sites such as Facebook, Instagram, and Snapchat have all helped to shape an economy of attention (Davenport \& Beck, 2001; Wu, 2016) which thrives upon the discovery, wide dispersal, and imitation of attractive content. This was fertile ground for the resuscitation of the 'meme' meme, an idea that had not proved to have the right traits to survive in the caustic environment of scholarship but which, once mutated into a far simpler form, began to flourish with incredible energy. Knobel and Lankshear (2007) talk of the 'popular “appropriations” of "meme” as a word to describe particularly "infectious" phenomena' (p. 199), in a decidedly unmemetic framing which seems to deny any agency to the meme itself while at the same time underlining just how far away this use of memes is from that understood by 'serious students and theorists of memes' (ibid.). Of course, if the central premise of memetics is true, then this change in the meaning and use of 'meme' is just an example of mutation and adaptation. Scholars were inefficient hosts, poor 'survival machines’ (to use Dawkins' phrase), whereas general netizens concerned with sharing cat pictures and poking each other on Facebook provided far more fertile ground. As a consequence, the 'meme concept has enthusiastically been picked up by Internet users' (Shifman, 2013, p. 364) and become 'a popular term for describing 
“catchy” and widely propagated ideas or phenomenon’ (Knobel \& Lankshear, 2007, p. 201).

So, most people who use the term 'meme' and, indeed, most people who create online 'memes' have little to no knowledge of the term's origins or its place in a scholarly field known as 'memetics'. In common web parlance, then 'meme' has little connection with anything other than entertaining shareable content. From a rhetorical perspective, its metaphorical power has been distinctly curtailed - the associations with genetics, survivability, selfish units of replication that use humans as survival machines, the whole panoply of Dawkins’ own extremely rich metaphorical constructions, have all largely disappeared. Indicative of this is the way in which those who actually wish to produce negative rhetorical associations around the idea of online memes need to introduce other metaphors in order to do so. So, Rodley (2016) talks about 'when memes go to war' (para. 25), and Wall and Mitew (2018) discuss 'meme warfare’, as does Boyd (2002). Olsen’s (2018) piece in Salon.com describes memes as being 'weaponized for political propaganda' and Neuman's (2012) article for NPR's website speaks of political memes being 'fast, cheap and out of control' (personifying them with a Dawkinian agency that is chaotic in its inability to be managed). In a weighty report published by the Institute for the Future, on The Biology of Disinformation, Rushkoff et al. (2018) state that 'memes are better understood as independent actors in a competitive battle of ideas' (p. 9) which seems designed to make them sound like lone wolf terrorists. Indeed, they explain that this independence is why 'teenagers in Russia can launch effective memetics assaults on Americans' (ibid.). Rushkoff is himself a long-time populariser of the 'meme' meme, having published the influential Media Virus! Hidden Agendas in Popular Culture (note 
the exclamation point and the implication of secret motivations) way back in 1996. We can see here that commentators (of both scholarly and more journalistic motivations) need to extend the idea of the meme with metaphors of battle and weapons in order to make it alarming or attention-grabbing within a discussion of propaganda or political communication. Their audiences do not associate the idea of the meme with anything threatening and so they need to rhetorically provide that threat through metaphors of war in order to persuade people that image macros and YouTube videos can indeed have serious or harmful effects on a country’s political existence.

The metaphor of communication as virus has lost power in the same way that the original metaphor of the meme (as introduced by Dawkins) has. To describe something as being like a virus is no longer pejorative. The virus no longer shares the same associations of revulsion and fear that Hitler played on with his heavy use of infestation metaphors. Modern communication technologies have rehabilitated the virus. They have made infection a pleasant thing, an entertaining thing, something that friends do to friends. Perhaps indicative of this is the fact that when I search for the phrase 'viral propaganda' on Google in the United Kingdom, the first seven entries all relate to a music public relations company called, Viral Propaganda - a construction which hints at both an ironic rehabilitation of the term 'propaganda' but also clearly echoes the positive (if opportunistic) attitude towards infectious messaging that marketing communication has incubated since the 1990s.

Perhaps the most important consequence of the metaphor of virality losing its negative associations is that it becomes something that we (scholars, journalists, commentators, and the general public) now find it difficult to be alarmed by. Linnemann 
et al. (2014) have argued that the 'zombie talk' that has spread across modern media in the form of 'zombie apocalypse' content has acted not just as a fashionable entertainment genre but also as 'part of a larger ideological frame that normalizes state violence and conceals the fundamental inequalities of late capitalism' (p. 507). In a similar way, the viral metaphor that has been happily accepted by marketers, consumers, politicians, lobbyists, and extremists alike normalises the exploitation of influencers, audiences, and communities for the dissemination of their targeted messages. If it is a normal thing to do, it also becomes an easy thing to dismiss. This is why, as we have seen, those wishing to raise awareness of how memes are being used to influence political debates need to transform or re-frame the terms of the metaphor by talking of memetic warfare and the weaponisation of memes - such alterations serve rhetorically to help readers see viral communication is a different way. Others have tried to solve this problem by going back to the biological details of the viral metaphor and expanding them considerably. Rushkoff et al. (2018), for example, resurrect some of the memetic science approaches of the 1990s and early 2000s, applying evolutionary biological terms and concepts to try to discover ways to defend against manipulative memes. They advance strategies of early detection, immunisation and containment that the left might use in order to combat infectious disinformation from the extreme right. Their approach, rhetorically, is an attempt to revivify the contagion metaphor for communication, injecting back some of the original unease, revulsion, and urgency that was naturally associated with infection in the public mind. It is also indicative that Rushkoff et al. (2018) are talking from a position on the US left. At this moment in time, it seems undeniable that the US alt-right have demonstrated a great facility with 'weaponised' memes. Communities around the boards 
4chan $/ \mathrm{pol} /$ and 8chan/pol/, in particular, have a keen awareness of how to infect mainstream media with viral content that aids their cause and confounds their enemies while doing it with an eye to entertainment and 'LULZ' that comes directly from the positive re-framing of viral communication that has occurred as the Internet has made everyone a 'marketer'.

\section{Metaphorical Memes}

While discourses around memes and viral communication are clearly grounded in metaphorical positionings, then, it is logical to ask whether there is something inherently metaphorical about the sorts of messages that are successful in contagious political communication?

As we have seen, for some researchers, metaphor is 'the very constitutive ground of language' (Jaynes, 1976, p. 48). McVeigh (2016), indeed, memorably suggests that thinking should be 'considered a collection of metaphors shaped by history' (p. 22). Metaphors help us understand the world, and can be used to persuade us to see the world in a different way, they are 'not simply descriptive, but transformative' (p. 25) - 'change the dominant metaphors, and the mental paradigm changes' (p. 26). So, in this chapter, we have been exploring the effect upon our understanding of political communication and persuasion that the use of the viral, or contagion, metaphor has. Yet, what of the sorts

of messages that become memes, the types of content that are susceptible to the exponential growth of the viral distribution model? Do we find that political memes are particularly metaphorical? 
Certainly, researchers have found that modern mass-mediated political discourse makes much use of metaphorical constructions. Musolff (2004, 2016, 2017), for example, has consistently explored the power of analogical and metaphorical figures in European political communication. In a recent study (Musloff, 2017), he brings large-scale corpus analysis techniques to bear upon an examination of the 'discourse career' (p. 98) of one particular metaphor (that of the UK being at the heart of Europe) across the EUROMETA press text corpus running from 1989 to 2016. The analysis uncovered the 'range of types of uses' that the metaphor was put to and 'shed light on the pragmatic factors underlying the resuscitation, ironical reversal and further sarcastic exploitation of the metaphor' (p. 98). At the other end of the methodological spectrum, Kjeldsen's (2000) detailed analysis of how a visual representation of a bicycle helmet functions metaphorically in a single print ad for the Danish SDP in the 1998 national election is a tour-de-force of qualitative exposition, plumbing the complexities of the shifting terms of the metaphor and their resonances for the Danish public.

There has also been some significant research specifically targeting memetic or viral political communication which has underlined the importance of metaphor in successful contagious messaging. So, Huntington's $(2013,2016)$ work has sought to trace the visual rhetorical devices common across political memes (particularly those arising from alternative, grassroots political protest) and has fixed in particular upon metaphor, synecdoche, and intertextuality as central figures. Her analysis of the visual rhetoric behind Pepper Spray Cop memes demonstrates just how much nuance a keen sensitivity to the working of metaphor can bring to an appreciation of apparently simple visual communication tropes. Piata (2016) has tracked the interplay between journey metaphors 
and humour in her study of political advertising and memes in the 2015 election in Greece.

However, much of the extant research on political viral communication makes little reference to metaphorical content. So, for example, Lee and Campbell's (2016, see also Campbell and Lee, 2016) study of what they dub OPPs ('online political posters', which are image macros employed in the service of party political communication on platforms such as Facebook) does investigate the thematic content of these messages but restricts itself to easily quantified codes such as general sentiment (negative/positive/other), visual presence of a party figure, policy focus or image focus, and so on. Certainly, some of the example OPPs that they provide do have clear metaphorical content (such as the image of then Labour leader, Ed Miliband, being in the pocket of the SNP's Alex Salmond) but an exploration of figurative language is beyond the interests of their study. In this sense, Lee and Campbell reflect the more macro-level perspective of the majority of political communication researchers towards viral/memetic messaging. This, of course, leaves an important research gap that future scholarship must seek to fill.

\section{Conclusion}

Virality is a metaphor for a form of content dissemination. It is not, directly, a metaphor for content. However, in order for a piece of content to lend itself to being spread across a population exponentially it must have certain characteristics. These characteristics can then be said to make it 'go viral'. These are 'rhetorical techniques deployed to improve their replication' (Sparkes-Vian, 2019). As with all rhetorical techniques, there is no easy recipe for their selection and combination. Rhetoric teaches the communicator an appreciation of kairos, or the right moment, and prepon, or 'the non-rational, inexplicable 
intuition of adequacy and propriety' (Cahn, 1989, p. 128). These are exactly the qualities that any creator of viral content needs in order to determine what rhetorical techniques (selection of metaphor, imagery, patterns, type of proof, etc.) are best suited for a particular audience at a particular time. These are also the qualities that are difficult to provide easy guides for. They require an intimate knowledge of the audience and their social and political environment and an acknowledgement of the fact that those audiences and environments are dynamic, constantly changing. 'Computational propaganda', the 'use of algorithms, automation, and human curation to purposefully distribute misleading information over social media networks' (Woolley \& Howard, 2017, p. 1) can go some way in substituting for these human qualities but for the most effective messaging the human, rhetorical element remains essential. The changing connotations of the viral metaphor examined in this chapter demonstrate the ways in which rhetorical power is always contingent upon shifting audience understanding. However, even dead or heavily transformed metaphors still contain frames that influence the way we think about the world (Lakoff \& Johnson, 2003). There is some evidence, particularly in the wake of the Brexit referendum and the 2016 US election, that the environment is once again changing as various publics discover that they have been infected without their knowledge, victims of micro-targeted rhetorical payloads which take advantage of data scraped from their web habits to ensure effective kairos and prepon. Perhaps the idea that virality and the meme are simply empowering, entertaining features of the modern web is becoming a lot more nuanced as we rediscover the unbalancing force of contagious political rhetoric and once more realise the infectious power of words. 


\section{References}

Aristotle (2004). The Art of Rhetoric. (Trans. H.C. Lawson-Tancred). London: Penguin Books.

Armitstead, C. (2017). Dawkins sees off Darwin in vote for most influential science book. The Guardian, 20th July 2017. Available at: www.theguardian.com/books/booksblog/2017/jul/20/dawkins-sees-off-darwinin-vote-for-most-influential-science-book [Accessed 30th July 2018].

Aunger, R. (Ed.) (2003). Darwinizing Culture: The Status of Memetics as a Science. Oxford: Oxford University Press.

Black, E. (1965). Rhetorical Criticism. New York: Macmillan.

Black, E. (1970). The second persona. Quarterly Journal of Speech, 56(2), 109-119. https://doi.org/10.1080/00335637009382992

Blackmore, S. (2003). The 'new science of memetics': The case for. Think, 2(5), 2126. https://doi.org/10.1017/S1477175600002554

Boyd, A. (2002). Truth is a virus: Meme warfare and the Billionaires for George Bush (or Gore). In S. Duncombe (Ed.), Cultural Resistance Reader (pp. 369-375). New York: Verso. 
Bradie, M. (2003). The 'new science of memetics': The case against. Think, 2(5), 2730. https://doi.org/10.1017/S1477175600002566

Burman, J. T. (2012). The misunderstanding of memes: Biography of an unscientific object, 1976-1999. Perspectives on Science, 20(1), 75-104. https://doi.org/10.1162/POSCa00057

Cahn, M. (1989). Reading rhetoric rhetorically: Isocrates and the marketing of insight. Rhetorica, 7(2), 121-144.

Calvin, W. H. (1997). The six essentials? Minimal requirements for the Darwinian bootstrapping of quality. Journal of Memetics-Evolutionary Models of Information Transmission, 1, 1-9.

Campbell, V. \& Lee, B. (2016). Party branding: A case study of online political posters. In D. Lilleker \& M. Pack (Eds.), Political Marketing and the 2015 UK General Election. London: Palgrave, pp. 49-65.

Cassin, B. (2014). Sophistical Practice: Towards a Consistent Relativism. New York: Fordham University Press.

Davenport, T. \& Beck, J. (2001). The Attention Economy: Understanding the New Currency of Business. Boston: Harvard Business School Press.

Dawkins, R. (2016). The Selfish Gene. Oxford: Oxford University Press.

Distin, K. (2006). The Selfish Meme: A Critical Reassessment. Cambridge: Cambridge University Press. 
Fahnestock, J. (2011). Rhetorical Style: The Uses of Language in Persuasion. Oxford: Oxford University Press.

Foss, S. (2003). Rhetorical Criticism: Exploration \& Practice. Long Grove, Il.: Waveland Press.

Gabora, L. (1997). The origin and evolution of culture and creativity. Journal of Memetics: Evolutionary Models of Information Transmission, 1(1), 1-28.

Gatherer, D. (1998). Why the thought contagion metaphor is retarding the progress of memetics. Journal of Memetics-Evolutionary Models of Information Transmission, 2(2), 135-158.

Ganor, B. (2015). Four questions on ISIS: A 'trend' analysis of the Islamic State. Perspectives on Terrorism, 9(3), 56-64.

Godin, S. (2000) Unleashing the Ideavirus. Available at: https://sethgodin.typepad.com/seths_blog/files/2000Ideavirus.pdf [Accessed 3rd August 2018].

Guadagno, R. E., Rempala, D. M., Murphy, S., \& Okdie, B. M. (2013). What makes a video go viral? An analysis of emotional contagion and Internet memes. Computers in Human Behavior, 29(6), 2312-2319. https://doi.org/10.1016/j.chb.2013.04.016

Hoffman, D. L. \& Novak, T. P. (1996). Marketing in hypermedia computer-mediated environments: Conceptual foundations. Journal of Marketing, 60(3), 50-68. https://doi.org/10.2307/1251841 
Huntington, H. E. (2013). Subversive memes: Internet memes as a form of visual rhetoric. Selected Papers of Internet Research, ir14. Available at: https://journals.uic.edu/ojs/index.php/spir/article/view/8886/7085

Huntington, H. E. (2016). Pepper spray cop and the American dream: Using synecdoche and metaphor to unlock internet memes' visual political rhetoric. Communication Studies, 67(1), 77-93.

Jantke, K. (2004). The biotope issue in meme media implementations. In Proceedings of the 2004 International Conference on Intuitive Human Interfaces for Organizing and Accessing Intellectual Assets (pp. 99-107). Berlin: Springer.

Jaynes, J. (1976). The Origins of Consciousness in the Breakdown of the Bicameral Mind. Boston, MA: Houghton Mifflin.

Jeffreys, M. (2000). The meme metaphor. Perspectives in Biology and Medicine, 43(2), 227-242. https://doi.org/10.1353/pbm.2000.0004

Kilpinen, E. (2008). Memes versus signs: On the use of meaning concepts about nature and culture. Semiotica, 2008(171), 215-237. https://doi.org/10.1515/SEMI.2008.075

Kjeldsen, J. E. (2000). What the Metaphor Could Not Tell Us About the Prime Minister's Bicycle Helmet. Nordicom Review, 21(2), 305-327. 
Knobel, M. \& Lankshear, C. (2007). Online memes, affinities, and cultural production. In M. Knobel \& C. Lankshear (Eds.), A New Literacies Sampler. New York: Peter Lang, pp. 199-227.

Lakoff, G. \& Johnson. M. (2003). Metaphors We Live By. Chicago, IL: The University of Chicago Press.

Lee, B. \& Campbell, V. (2016). Looking out or turning in? Organizational Ramifications of online political posters on Facebook. International Journal of Press/Politics, 21(3), 313-337.

Loach, J. (2006). Revolutionary pedagogues? How Jesuits used education to change society. In J. O'Malley, G. Bailey, S. Harris, T. Kennedy (Eds.), The Jesuits II: Culture, Society, and the Arts 1540-1773. Toronto: University of Toronto Press, pp. 66-85.

Linnemann, T., Wall, T., \& Green, E. (2014). The walking dead and killing state: Zombification and the normalization of police violence. Theoretical Criminology, 18(4), 506-527. https://doi.org/10.1177/1362480614529455

Lissack, M. R. (2004). The redefinition of memes: Ascribing meaning to an empty cliché. A Journal of Complexity Issues in Organizations and Management, 5(3), 48-65.

Machiavelli, N. (trans. C. Lynch) (2005). The Art of War. Chicago, IL: University of Chicago Press.

Marsden, P. (1998). Memetics and social contagion: Two sides of the same coin. Journal of Memetics-Evolutionary Models of Information Transmission, 2(2), 171-185. 
Marsden, P. (2006). Introduction and summary. In J. Kirby \& P. Marsden (Eds.) Connected Marketing. Oxford: Butterworth-Heinemann, pp. 15-35.

Marwick, A. \& Lewis, R. (2017). Media Manipulation and Disinformation Online. New York: Data \& Society Research Institute. Available at: https://datasociety.net/output/media-manipulation-and-disinfo-online/ [Accessed 2nd August 2018].

McVeigh, B. (2016). A Psychohistory of Metaphors. London: Lexington Books.

Miles, C. (2014). The rhetoric of managed contagion: Metaphor and agency in the discourse of viral marketing. Marketing Theory, 14(1), 3-18. https://doi.org/10.1177/1470593113506433

Musolff, A., 2004. Metaphor and Political Discourse. Analogical Reasoning in Debates About Europe. Basingstoke: Palgrave Macmillan.

Musolff, A., 2016. Political Metaphor Analysis: Discourse and Scenarios. London: Bloomsbury.

Musolff, A. (2017). Metaphor, irony and sarcasm in public discourse. Journal of Pragmatics, 109, 95-104.

Neuman, S. (2012). Political memes: Fast, cheap and out of control? Available at: www.npr.org/sections/itsallpolitics/2012/10/24/163552936/political-memesfast-cheap-and-out-of-control [Accessed 1st August 2018]. 
Olsen, D. (2018). How memes are being weaponized for political propaganda. Available at: www.salon.com/2018/02/24/how-memes-are-being-weaponized-forpolitical-propaganda/ [Accessed 30th July 2018].

O'Shaughnessy, N. (2004). Politics and Propaganda: Weapons of Mass Seduction. Manchester: Manchester University Press.

Ott, B. \& Dickinson, G. (2013). Entering the unending conversation: An introduction to rhetorical criticism. In B. Ott \& G. Dickinson (Eds.) The Routledge Reader in Rhetorical Criticism. London: Routledge, pp. 1-13.

Perry, S. (1983). Rhetorical functions of the infestation metaphor in Hitler's rhetoric. Central States Speech Journal, 34(4), 229-235. https://doi.org/10.1300/J009v25n03

Piata, A. (2016). When metaphor becomes a joke: Metaphor journeys from political ads to internet memes. Journal of Pragmatics, 106, 39-56.

Potter, J. (2005). Representing Reality: Discourse, Rhetoric and Social Construction. London: Sage.

Rayport, J. (1996). The virus of marketing. Fast Company (6th December 1996/January 1997), 68. Available at: www.fastcompany.com/27701/virusmarketing [Accessed 4th August 2018].

Reames, R. (2012). The $\mu \tilde{v} \theta$ o of pernicious rhetoric: The Platonic possibilities of

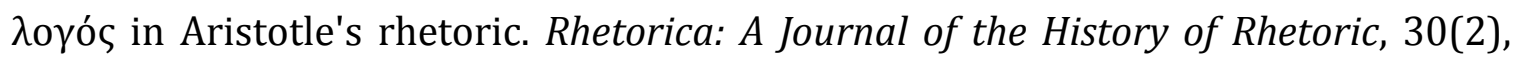
$134-152$. 
Richards, I. A. (1964). The Philosophy of Rhetoric. Oxford: Oxford University Press.

Rodley, C. (2016). When memes go to war: Viral propaganda in the 2014 Gaza-Israel Conflict. The Fibreculture Journal, 27(FCJ-200), 1-31. https://doi.org/10.15307/fcj.27.200.2016

de Romilly, J. (1975). Magic and Rhetoric in Ancient Greece. Cambridge: Harvard University Press.

Rose, N. (1998). Controversies in meme theory. Journal of Memetics, 2(1), 66-76.

Rushkoff, D. (1996). Media Virus! Hidden Agendas in Popular Culture. New York: Ballantine Books.

Rushkoff, D., Pescovitz, D., \& Dunagan, J. (2018). The Biology of Disinformation. Available at: $\quad$ www.iftf.org/fileadmin/userupload/images/DigIntel/SR2002IFTFBiologyofdisinformationtk_042618.pdf [Accessed 1st August 2018].

Schiappa, E. (1990). Did Plato coin rhetorike? American Journal of Philology, 111(4), 457-470. https://doi.org/10.2307/295241

Schumpeter, J. (2003). Capitalism, Socialism and Democracy. London: Routledge.

Shifman, L. (2012). An anatomy of a YouTube meme. New Media and Society, 14(2), 187-203. https://doi.org/10.1177/1461444811412160 
Shifman, L. (2013). Memes in a digital world: Reconciling with a conceptual troublemaker. Journal of Computer-Mediated Communication, 18(3), 362-377. https://doi.org/10.1111/jcc4.12013

Shifman, L. \& Thelwall, M. (2009). Assessing global diffusion with web memetics: The spread and evolution of a popular joke. Journal of the American Society for Information Science and Technology, 60(12), 2567-2576. https://doi.org/10.1002/asi

Sontag, S. (1978). Illness as Metaphor. New York: Farrar, Straus and Giroux.

Sparkes-Vian, C. (2019). Digital propaganda: The tyranny of ignorance. Critical Sociology, 45(3), 393-409. https://doi.org/10.1177/0896920517754241

Taylor, P. (2003). Munitions of the Mind: A History of Propaganda From the Ancient World to the Present Day. Manchester: Manchester University Press.

Wall, T. \& Mitew, T. (2018). Swarm networks and the design process of a distributed meme warfare campaign. First Monday, 22(5-7), 1-33. https://doi.org/10.5210/fm.v23i5.8290

Wardy, R. (2005). The Birth of Rhetoric: Gorgias, Plato and Their Successors. London: Routledge.

Wiggins, B. E. (2016). Crimea river: Directionality in memes from the RussiaUkraine conflict. International Journal of Communication, 10, 451-485. 
Wiggins, B. E. \& Bowers, G. B. (2015). Memes as genre: A structurational analysis of the memescape. New Media and Society, 17(11), 1886-1906. https://doi.org/10.1177/1461444814535194

Woolley, S. \& Howard, P. (2017). Computational Propaganda Worldwide: Executive Summary. Computational Propaganda Research Project, Working Paper 2017.11. Oxford: Project on Computational Propaganda. Available at: https://comprop.oii.ox.ac.uk [Accessed 3rd August 2018].

Wu, T. (2016). The Attention Merchants. London: Atlantic Books.

Zipes, J. (2008). What makes a repulsive frog so appealing: memetics and fairy tales. Journal of Folklore Research, 45(2), 109-143. https://doi.org/10.1353/jfr.0.0011 